\title{
Potential Inhibition of Ehrlich Ascites Carcinoma by Naja Nubiae Crude Venom in Swiss Albino Mice
}

\author{
Ayman Saber Mohamed 1,", Mahmoud Abd Elkareem Mustafa ${ }^{2}$, Amel Mahmoud Soliman ${ }^{3}$, Sohair \\ Ramadan Fahmy ${ }^{4}$
}

1 Zoology Department - Faculty of Science - Cairo University -12613, Giza, Egypt; ayman81125@cu.edu.eg (A.S.M.); mahmoudabdelkareem3@gmail.com (M.A.M.); soliman.ame15@gmail.com (A.M.S.); sohairfahmy@gmail.com (S.R.F.);

* Correspondence: ayman81125@cu.edu.eg (A.S.M);

Scopus Author ID 56564677600

Received: 5.10.2021; Revised: 2.11.2021; Accepted: 5.11.2021; Published: 28.11.2021

\begin{abstract}
Cancer, the uncontrolled growth of cells, is a noteworthy cause of death globally. The present investigation attempted to study the potential efficacy of the Naja nubiae snake venom (NNSV) against Ehrlich Ascites Carcinoma (EAC) bearing mice. The LD50 was determined using twenty female mice (5 per group). The groups were given saline (Control) or venom $(0.2,0.46,0.6 \mathrm{mg} / \mathrm{kg}$ ) by intraperitoneal route. For the main experiment, fifty female mice were divided into five groups $(\mathrm{n}=10)$ : all groups except groups I and II received EAC cells intraperitoneal. All EAC bearing mice received intraperitoneal saline (EAC control), $0.034 \mathrm{mg} / \mathrm{kg} \mathrm{NNSV}, 0.017 \mathrm{mg} / \mathrm{kg} \mathrm{NNSV}$, and reference drug (5fluorouracil, $20 \mathrm{mg} / \mathrm{kg}$ body weight i.p.), respectively. In NNSV-treated mice, there were significant reductions in tumor volume, tumor cell counts, tumor cell viability, total WBC count, MDA, urea, uric acid, AST, ALT, and ALP levels. Red blood cell count, hemoglobin content, platelets, glutathione, and catalase levels increased significantly in NNSV-treated mice. The architecture of the hepatic and renal architecture in mice treated with NNSV was improved histopathologically. The effect of NNSV against Ehrlich Ascites Carcinoma was inversely dose-dependent.
\end{abstract}

Keywords: Naja nubiae; venom; cobra; Ehrlich ascites carcinoma; antitumor.

(C) 2021 by the authors. This article is an open-access article distributed under the terms and conditions of the Creative Commons Attribution (CC BY) license (https://creativecommons.org/licenses/by/4.0/).

\section{Introduction}

Cancer, the uncontrolled growth of cells, is a noteworthy cause of death globally [1]. It is reported that around 140,690 cases were accounted for cancer in 2019 [2]. Using chemotherapy and radiotherapy to treat tumors is accompanied by many side effects such as harmful reactions on normal cells and great reoccurrence danger [3]. In this way, it is necessary to change malignancy treatment from chemotherapy to biotherapy, utilizing biological agents with minimal or no adverse effects [3]. Indeed, snake venom's anticancer activities represent one of its most appealing remedial highlights and have been effectively explored and investigated over the previous decade [4].

Snake venom is a complex mixture of numerous substances, for example, activators, toxins, enzymes, growth factors, and inhibitors with a broad spectrum of biological activities[5]. Due to the various researches concerning snake venoms as anticancer agent sight hold the next miracle for treating cancer [6]. It demonstrates antitumor activity by killing the tumor cells directly, inhibiting tumor angiogenesis, or suppressing tumor growth [7]. The authentic cobras, genus Naja, are among the most familiar and iconic of all snakes. Naja is 
distributed throughout Africa and Asia [8]. The Nubian spitting cobra (Naja nubiae) is a species of spitting cobra native to Africa [9].

The purpose of this research was to investigate the potential therapeutic effect of the spitting cobra (Naja nubiae) crude venom against Erhlich ascites carcinoma in Swiss albino mice.

\section{Material and methods}

\subsection{Chemicals.}

5- Fluorouracil (Sandoz, B.p pharma) was purchased from (El Esaaf) pharmacy (Downtown, EGYPT). Spectrum Diagnostics (Obour City, EGYPT) provided the aminotransferase enzymes (ASAT, ALAT) kits, while Biodiagnostic provided the other kits (El Tahrir St, Dokki, EGYPT).

\subsection{Venom collection, preparation, and storage.}

The Department of Wild Life Management and Zoo Medicine, Faculty of Veterinary Medicine, Suez Canal University, identified the Nubian spitting cobra. Ten specimens of Naja nubiae snakes were captured from the Nubian area (Aswan, Egypt) in April 2017. Snakes were kept alive in separate plastic containers with free access to food (mice) and water. The crude venom was milked from the cobra following the "Mirtschin technique". Snakes were forced to bite through a para-film membrane, which was stretched over a $70 \mathrm{ml}$ vial. The venom was collected in the vial below the membrane. It was mixed with sterile distilled water in a 1:10 ratio, lyophilized using a lyophilizer (LABCONCO lyophilizer, shell freeze system, USA), and kept at $-20 \mathrm{C}^{\mathrm{o}}$.

\subsection{Experimental animals.}

Female Swiss albino (Mus musculus) mice weighing 25-30 g were used in all experiments. The animals were kept in polycarbonate boxes with steel-wire covers and wood shavings as bedding. They were fed a conventional laboratory diet and had unlimited access to water.The animals were kept under fixed conditions of housing temperatures of $18-23^{\circ} \mathrm{C}$ with 40-60\% humidity, light cycle 14-hour light/10-hour dark.

\subsection{Ethical consideration.}

Institutional Animal Care and Use Committee in Cairo University approved experimental protocols and procedures (CU-I-F 89/17).

\subsection{Acute toxicity study $\left(L D_{50}\right)$.}

The venom's LD50 was estimated using Aliu's arithmetic approach [10]. The groups were given saline (Control) or venom $(0.2,0.46,0.6 \mathrm{mg} / \mathrm{kg})$ by intraperitoneal route. The animals were then monitored for signs and symptoms of toxicity and death for the next 24 hours. The $\mathrm{LD}_{50}$ was calculated using the formula:

LDy $=$ Highest dose $\left(\mathrm{LD}_{100}\right)$.

$\mathrm{N}=$ Number of animals per group; $\mathrm{Dd}=$ Dose difference; $\mathrm{Md}=$ Mean dead; $\mathrm{LD}_{50}=$ Dose that killed $50 \%$ of test animals; $\mathrm{LD}_{100}=$ Dose that killed $100 \%$ (all) the test animals. 
2.6. Induction of Ehrlich ascites carcinoma (EAC).

Ehrlich ascites tumors were kindly provided by the Egyptian National Cancer Research Center (NCRC). The parent line was kindly supplied by the National Cancer Institute, Cairo University, Egypt. Under aseptic settings, ascites fluid was removed from tumor-bearing animals through needle aspiration from the peritoneal cavity. The Trypan blue dye exclusion approach was used to count ascites tumor cells in a Neubauer hemocytometer. The animals used for the experiment received $0.2 \mathrm{ml}$ i.p. of a suspension containing $5 \times 106$ Ehrlich tumor cells. The preparation of the suspension containing tumor cells was done according to Dagli et al. [11].

\subsection{Experimental design.}

Female Swiss albino mice (50) were divided into five groups $(\mathrm{n}=10)$ as follows: Group I (Control): mice were daily injected intraperitoneally with $0.2 \mathrm{ml}$ physiological saline from the $0^{\text {th }}$ day until the end of the experiment $\left(10^{\text {th }}\right.$ day). Group II (EAC): mice were inoculated with EAC cells $\left(5 \times 10^{6}\right.$ cells/mouse i.p. $)$ on the $0^{\text {th }}$ day; then, they were injected intraperitoneally with $0.2 \mathrm{ml}$ physiological saline for nine consecutive days.Group III $(0.034$ $\mathrm{mg} / \mathrm{kg} \mathrm{NNSV})$ : mice were treated with venom $(0.034 \mathrm{mg} / \mathrm{kg}$, i.p. $)$ on the $1^{\text {st }}, 4^{\text {th }}$, and $7^{\text {th }}$ day.Group VI (EAC+ $0.034 \mathrm{mg} / \mathrm{kg}$ NNSV): mice were inoculated with EAC cells $(5 \times$ $10^{6}$ cells/mouse i.p.) on the $0^{\text {th }}$ day; then, they were treated with venom $(0.017 \mathrm{mg} / \mathrm{kg}$, i.p. $)$ at $1^{\text {st }}, 4^{\text {th }}$ and $7^{\text {th }}$ day.Group V (EAC +5 - Fluorouracil): mice were inoculated with EAC cells $(5$ $\times 10^{6}$ cells/mouse i.p.) on the $0^{\text {th }}$ day; then, they were treated daily with reference drug (5-Fu, $20 \mathrm{mg} / \mathrm{kg}$, i.p.) from $1^{\text {st }}$ to $9^{\text {th }}$ day[12].

Animals from all groups were euthanized on the tenth day with an overdose of sodium pentobarbital (100 mg/Kg) [13] for measurement of antitumor and biochemical param-eters in addition to histopathological examination.

\subsection{The antitumor parameters.}

The ascitic fluid from treated groups was collected for the immediate determination of ascites tumor volume. PCV was determined by centrifuging the ascetic fluid in a capillary tube at 10,000 RPM for five minutes. The volume of packed Ehrlich ascites tumor cells divided by the ascitic fluid sample's total volume gave the PCV. The total count and viability of Ehrlich ascites tumor cells were calculated using a hemocytometer and dye exclusion technique, respectively [14]. The viability percentage was calculated according to the following equation:

$$
\% \text { Viable cells }=\frac{\text { No.of viable cells }}{\text { Total cells }} \times 100
$$

\subsection{Samples preparations.}

Blood was collected from all animal groups in tubes containing EDTA for hematological assays and biochemical analysis. The blood samples were centrifuged at 3000 rpm for 20 minutes [15]. The collected serum was stored at -20 oC until used for biochemical assays. Liver and kidney tissues were homogenized $(10 \% \mathrm{w} / \mathrm{v})$ in ice-cold $0.1 \mathrm{M}$ Tris-HCl buffers (pH7.4). The homogenate was centrifuged at $3000 \mathrm{rpm}$ for $15 \mathrm{~min}$. at $4{ }^{\circ} \mathrm{C}$, and the resultant supernatant was used for the biochemical analyses [16]. 


\subsection{Biochemical parameters.}

The accessible kits were used for estimation of serum aminotransferase enzymes (ASAT \& ALAT) activities, serum alkaline phosphatase (ALP), serum creatinine, urea, uric acid, malondialdehyde (MDA), glutathione reduced (GSH), and catalase was determined in the liver and kidney homogenate supernatant as indicated by the producer's directions utilizing Biodiagnostic (Giza, Egypt)

\subsection{Histopathologic study analyses.}

For histological evaluation, liver and kidney tissues were fixed in 10\% formal saline, embedded in paraffin, sectioned, and stained with hematoxylin and eosin under a light microscope (40X) [17].

\subsection{Statistical significance.}

The statistical analysis was performed using SPSS program for Windows (version $15.0)$. Values were expressed as means \pm SE. A one-way analysis of variance was used to analyze the comparisons between groups (ANOVA). Duncan's post hoc test was used to compare the group means, and $\mathrm{p}<0.05$ was considered statistically significant.

\section{Results and Discussion}

\subsection{Determination of $L D_{50}$ of Naja nubiae snake venom (NNSV).}

During the monitoring period, none of the animals in Group A showed any clinical or behavioral abnormalities. Depression, weakness, and loss of appetite were noted in Groups C and $\mathrm{D}$ administered with the greater doses of extracted venom in the first 5 hours. All animals in Group A and B were active all through the study (Table 1). In Group C, four animals suffered depression, weakness, and loss of appetite, and they eventually died within 24 hours. In Group $\mathrm{D}$, all five animals suffered depression, weakness, and loss of appetite, and they eventually died within 24 hours. By applying the formula:

$$
\begin{gathered}
\mathrm{LD} 50=\mathrm{LDy}-\frac{\Sigma(\mathrm{Dd} \times \mathrm{md}}{\mathrm{N}} \\
\mathrm{LD} 50=0.6-\frac{1.3}{5}=0.34 \mathrm{mg} / \mathrm{kg}
\end{gathered}
$$

Table 1. Determination of $\mathrm{LD}_{50}$ of the extracted NNSV in mice.

\begin{tabular}{c|c|c|c|c} 
Dose & No. of death & Mean death & $\begin{array}{c}\text { Dose } \\
\text { diff. }\end{array}$ & Mean death x dose diff. \\
\hline Control & 0 & 0 & 0 & 0 \\
\hline $0.2 \mathrm{mg}$ & 0 & 0 & 0.2 & 0 \\
\hline $0.4 \mathrm{mg}$ & 4 & 2 & 0.2 & 0.4 \\
\hline $0.6 \mathrm{mg}$ & 5 & 4.5 & 0.2 & 0.9 \\
\hline Sum $(\Sigma)$ & - & & 1.3
\end{tabular}

3.2. Effect of NNSV on tumor markers of EAC-bearing mice.

Snake venoms show the highest cytotoxic potential since ophidian accidents cause a large amount of tissue damage, suggesting a good utilization of these venoms or their components as antitumor agents [18]. Data presented in Table 2 showed that NNSV caused a significant decrease $(\mathrm{P}<0.05)$ in ascites fluid volume, packed cell volume, cells count, and 
viable cells percentage compared to the EAC group. The low dose of venom was more effective than the high dose. Ascites fluid constitutes an essential nutritional source for tumor cells [19]. The production of ascitic extracellular fluid in Ehrlich carcinoma is due to increased capillary permeability in the peritoneal cavity [20]. Furthermore, In EAC-bearing mice, the extensive formation of new capillary blood vessels (neovascularization or angiogenesis) provides more nutrients and oxygen supply to the fast-dividing EAC-cells leading to the induction of growth [21]. The administration of NNSV caused a significant decrease in the ascites fluid volume, packed cell volume, cells count, and viable cell percentage. The antitumor mechanisms of NNSV may be through modulating the critical processes of cellular proliferation, differentiation, apoptosis, angiogenesis, and metastasis.

Table 2. Effect of NNSV on tumor parameters of EAC-bearing mice.

\begin{tabular}{c|c|c|c|c}
\multirow{2}{*}{ Parameters } & \multicolumn{4}{|c}{ EAC } \\
\cline { 2 - 5 } & saline & $\begin{array}{c}\text { NNSV } \\
(0.034 \mathrm{mg} / \mathrm{kg})\end{array}$ & $\begin{array}{c}\mathrm{NNSV} \\
(0.017 \mathrm{mg} / \mathrm{kg})\end{array}$ & $\begin{array}{c}5-\mathrm{FU} \\
(20 \mathrm{mg} / \mathrm{kg})\end{array}$ \\
\hline Ascites fluid Volume $(\mathrm{ml})$ & $8.17 \pm 0.47$ & $7.08 \pm 0.39^{\mathrm{a}}$ & $5.22 \pm 0.35^{\mathrm{a}}$ & $2.54 \pm 0.28^{\mathrm{a}}$ \\
\hline Packed cell volume & $34.33 \pm 3.95$ & $23.33 \pm 2.17^{\mathrm{a}}$ & $19.17 \pm 1.89^{\mathrm{a}}$ & $17.65 \pm 0.35^{\mathrm{a}}$ \\
\hline Cells count $\left(10^{3}\right.$ cells $\left./ \mathrm{mm}^{3}\right)$ & $129.00 \pm 11.40$ & $98.50 \pm 16.39^{\mathrm{a}}$ & $71.17 \pm 6.83^{\mathrm{a}}$ & $65.35 \pm 0.5 .65^{\mathrm{a}}$ \\
\hline Viable cells $(\%)$ & $99.40 \pm 0.17$ & $80.68 \pm 0.18^{\mathrm{a}}$ & $57.71 \pm 0.14^{\mathrm{a}}$ & $48.32 \pm 0.19^{\mathrm{a}}$ \\
\hline Non-viable cells $(\%)$ & $0.60 \pm 0.03$ & $19.32 \pm 0.04^{\mathrm{a}}$ & $32.29 \pm 0.07^{\mathrm{a}}$ & $51.45+.09^{\mathrm{a}}$
\end{tabular}

Values are means \pm se $(n=10$ per group). a: significant compared with EAC group.

\subsection{Effect of NNSV on hematological parameters of EAC-bearing mice.}

Table 3 showed significant decreases $(P<0.05)$ in $\mathrm{Hb}$, RBCs, HCT, MCV, MCH, MCHC, PLT, lymphocytes, while WBCs, neutrophils, monocytes increased in NNSV and EAC tumor-bearing mice as compared to a control group. The treatment with NNSV and 5-FU restore the levels of the parameters near the normal.

Table 3. Effect of NNSV on hematological parameters of EAC-bearing mice.

\begin{tabular}{|c|c|c|c|c|c|}
\hline \multirow[b]{2}{*}{ Parameters } & \multirow[b]{2}{*}{ Control } & \multicolumn{4}{|c|}{ EAC } \\
\hline & & saline & $\begin{array}{c}\text { NNSV } \\
(0.034 \mathrm{mg} / \mathrm{kg})\end{array}$ & $\begin{array}{c}\text { NNSV } \\
(0.017 \mathrm{mg} / \mathrm{kg})\end{array}$ & $\begin{array}{c}5-\mathrm{FU} \\
(20 \mathrm{mg} / \mathrm{kg})\end{array}$ \\
\hline Hemoglobin (g/dl) & $11.85 \pm 0.09$ & $5.32 \pm 0.21^{\mathrm{a}}$ & $9.32 \pm 0.64^{b}$ & $11.43 \pm 0.17^{\mathrm{b}}$ & $11.02 \pm 0.21^{\mathrm{b}}$ \\
\hline $\begin{array}{l}\text { RBC's } \\
\left(\times 10^{12} / \mathrm{L}\right)\end{array}$ & $6.98 \pm 0.15$ & $3.67 \pm 0.09^{\mathrm{a}}$ & $5.15 \pm 0.4^{\mathrm{b}}$ & $6.65 \pm 0.16^{\mathrm{b}}$ & $6.82 \pm 0.13^{b}$ \\
\hline HCT $(\%)$ & $45.73 \pm 0.79$ & $22.83 \pm 0.94^{\mathrm{a}}$ & $33 \pm 1.4^{\mathrm{b}}$ & $40.72 \pm 0.47^{b}$ & $42.47 \pm 1.38^{b}$ \\
\hline MCV (fl) & $67.27 \pm 1.4$ & $50.6 \pm 1.6^{\mathrm{a}}$ & $61.58 \pm 3.49^{\mathrm{b}}$ & $61.37 \pm 1.24^{\mathrm{b}}$ & $63.98 \pm 1.22^{\mathrm{b}}$ \\
\hline $\mathrm{MCH}(\mathrm{pg})$ & $19.3 \pm 0.48$ & $13.87 \pm 0.26^{\mathrm{a}}$ & $17.4 \pm 0.45^{b}$ & $16.93 \pm 0.55^{b}$ & $17.32 \pm 0.29^{b}$ \\
\hline $\mathrm{MCHC} \%$ & $29.23 \pm 0.49$ & $23.03 \pm 0.39^{\mathrm{a}}$ & $28.48 \pm 1.17^{\mathrm{b}}$ & $27.58 \pm 0.71^{\mathrm{b}}$ & $27.1 \pm 0.57^{\mathrm{b}}$ \\
\hline $\begin{array}{l}\text { WBC's } \\
\left(\times 10^{3} / \mathrm{L}\right)\end{array}$ & $5.28 \pm 0.64$ & $7.15 \pm 0.3^{\mathrm{a}}$ & $5.85 \pm 0.15^{b}$ & $5.80 \pm 0.47^{b}$ & $5.65 \pm 0.08^{\mathrm{b}}$ \\
\hline PLT $\left(10^{3}\right.$ cells $\left./ \mathrm{mm}^{3}\right)$ & $902 \pm 51.7$ & $602 \pm 26.27^{\mathrm{a}}$ & $817 \pm 64.15^{\mathrm{b}}$ & $842 \pm 22.88^{b}$ & $840.5 \pm 44.6^{b}$ \\
\hline Neutrophils \% & $13 \pm 0.1$ & $40 \pm 0.82^{\mathrm{a}}$ & $24.83 \pm 1.87^{\mathrm{b}}$ & $22.5 \pm 2.02^{\mathrm{b}}$ & $15.17 \pm 0.87^{b}$ \\
\hline Lymphocyte \% & $77.5 \pm 1.71$ & $50.67 \pm 3.25^{\mathrm{a}}$ & $63.83 \pm 0.4^{\mathrm{b}}$ & $68.5 \pm 5.74^{\mathrm{b}}$ & $72.5 \pm 1.18^{\mathrm{b}}$ \\
\hline Monocytes \% & $5.5 \pm 0.34$ & $10.33 \pm 0.27^{\mathrm{a}}$ & $13.67 \pm 0.28$ & $9.67 \pm 0.91$ & $7.33 \pm 0.84$ \\
\hline
\end{tabular}

Values are means \pm se $(n=10$ per group). a: Significant compared with a control group. b: significant compared with the EAC group.

The therapeutic efficacy of a low dose of NNSV is more than the high dose. EACmice's anemia is mainly due to a reduction in RBC or hemoglobin percentage or both, which occur either due to iron deficiency or due to hemolytic or myelopathic conditions [22]. In consonance with the report of Mohamed (2021), the tumor's progression in the present 
investigation was accompanied by significant decreases in $\mathrm{Hb}, \mathrm{RBCs}$, platelet levels that may be due to the suppressive effect of EAC on bone marrow erythropoiesis [23]. The granulocytic leucocyto-sis observed in EAC mice may be due to the acute inflammatory response or stress resulting from the proliferation of Ehrlich cells [24]. On the other hand, restoring the hematological parameters in tumor-bearing mice after the treatment with NNSV confirms the antitumor activity of NNSV. These results revealed that NNSV exerted a less toxic effect on the hemopoietic system and selective tumor cell affinity [25].

\subsection{Effect of NNSV biochemical parameters of EAC-bearing mice.}

In the NNSV and EAC tumor-bearing mice groups, there was a substantial rise ( $<<$ 0.05) in AST, ALT, ALP, urea, creatinine, and uric acid levels compared to the control group. (Table 4). NNSV and 5-FU treatments significantly $(p<0.05)$ reduced the AST, ALT ALP, urea, creatinine, and uric acid levels compared to the EAC group. The therapeutic efficacy of a low dose of NNSV is more than the high dose. Inoculation of EAC cells into the mice significantly increased the activities of AST, ALT, and ALP. The use of free amino acids in the production of proteins by rapidly dividing tumor cells may cause liver enzyme activity to be disrupted [26]. Besides, it is established that EAC proliferation in mice causes kidney damage and elevated blood urea, creatinine, and uric acid. The rapid recovery of liver and kidney function markers demonstrates NNSV's anticancer effectiveness. The histological examination of liver and renal tissues further supported these findings. Furthermore, the drop in serum ALT and ALT levels in tumor-bearing animals could be due to gluconeogenesis suppression in the liver, resulting in the production of tumor cell protein. [28].

Table 4. Effect of NNSV on biochemical parameters of EAC-bearing mice.

\begin{tabular}{|c|c|c|c|c|c|}
\hline \multirow[b]{2}{*}{ Parameters } & \multirow[b]{2}{*}{ Control } & \multicolumn{4}{|c|}{ EAC } \\
\hline & & saline & $\begin{array}{c}\text { NNSV } \\
(0.034 \mathrm{mg} / \mathrm{kg})\end{array}$ & $\begin{array}{c}\text { NNSV } \\
(0.017 \mathrm{mg} / \mathrm{kg})\end{array}$ & $\begin{array}{c}5-\mathrm{FU} \\
(20 \mathrm{mg} / \mathrm{kg})\end{array}$ \\
\hline AST (U/ml) & $8.1 \pm 1.79$ & $27.17 \pm 2.37^{a}$ & $24 \pm 1.07^{b}$ & $14 \pm 2.67^{b}$ & $18.5 \pm 2.75^{b}$ \\
\hline ALT (U/ml) & $30.33 \pm 2.32$ & $57.72 \pm 3.52^{\mathrm{a}}$ & $35.36 \pm 6.8^{b}$ & $32.5 \pm 5.98^{b}$ & $42.9 \pm 6.32^{b}$ \\
\hline $\operatorname{ALP}(\mathrm{U} / \mathrm{ml})$ & $19.4 \pm 3.76$ & $47.08 \pm 2.35^{\mathrm{a}}$ & $29.62 \pm 3.59^{b}$ & $26.56 \pm 3.71^{b}$ & $33.3 \pm 4.87^{b}$ \\
\hline Urea $(\mathrm{g} / \mathrm{dl})$ & $33.16 \pm 6.3$ & $80.07 \pm 5.23^{a}$ & $59.37 \pm 6.41^{b}$ & $56.94 \pm 4.44^{b}$ & $61.83 \pm 4.08^{b}$ \\
\hline Creatinine $(\mathrm{g} / \mathrm{dl})$ & $0.9 \pm 0.09$ & $2.6 \pm 0.05^{\mathrm{a}}$ & $1.63 \pm 0.08^{b}$ & $1.57 \pm 0.07^{\mathrm{b}}$ & $1.71 \pm 0.03^{\mathrm{b}}$ \\
\hline Uric acid $(\mathrm{g} / \mathrm{dl})$ & $1.17 \pm 0.01$ & $2.15 \pm 0.03^{\mathrm{a}}$ & $1.37 \pm 0.01^{\mathrm{b}}$ & $1.25 \pm 0.02^{\mathrm{b}}$ & $1.18 \pm 0.03^{b}$ \\
\hline
\end{tabular}

Values are means \pm se ( $n=10$ per group). a: Significant compared with a control group. b: significant compared with the EAC group.

\subsection{Effect of NNSV on oxidative stress parameters of EAC-bearing mice.}

Significant decreases $(p<0.05)$ in GSH, GST, CAT levels were observed in NNSV and EAC groups. At the same time, MDA concentration increased compared to the control group (Table 5). Treatment with NNSV and 5-FU caused significant increases $(p<0.05)$ in liver and kidney GSH, GST, and CAT levels while MDA concentration decreased compared to the EAC group. Thus, the therapeutic efficacy of a low dose of NNSV is more than the high dose. The increased lipid peroxidation levels in the liver and kidney of tumor-bearing animals could be attributed to the observed decrease in GSH levels, GAT activity, and increased MDA concentration [29]. It is well documented that oxidative stress is highly deleterious to cells, and reactive oxygen species (ROS) are engaged in the etiology and progression of several diseases, including cancer [30]. Unfortunately, 5-FU treatment induced oxidative stress. Similarly, many studies indicated the contribution of oxidative stress of 5-FU chemotherapy- in many organs 
[31]. However, the treatment with NNSV inhibits hepatic and renal lipid peroxidation and improves EAC mice's antioxidant system.

Table 5. Effect of NNSV on liver and kidney oxidative stress parameters of EAC-bearing mice.

\begin{tabular}{|c|c|c|c|c|c|c|}
\hline \multirow[b]{2}{*}{ Parameters } & \multirow[b]{2}{*}{ Organ } & \multirow[b]{2}{*}{ Control } & \multicolumn{4}{|c|}{ EAC } \\
\hline & & & saline & $\begin{array}{c}\text { NNSV } \\
(0.034 \text { mg/kg) }\end{array}$ & $\begin{array}{c}\text { NNSV } \\
(0.017 \\
\text { mg/kg) }\end{array}$ & $\begin{array}{c}5-\mathrm{FU} \\
(20 \mathrm{mg} / \mathrm{kg})\end{array}$ \\
\hline \multirow{2}{*}{$\begin{array}{l}\text { MDA }(\mathrm{nmole} / \mathrm{mg} \\
\text { protein })\end{array}$} & Liver & $4.31 \pm 0.15$ & $8.23 \pm 0.58^{\mathrm{a}}$ & $6.69 \pm 0.6^{\mathrm{b}}$ & $5.19 \pm 0.6^{\mathrm{b}}$ & $6.32 \pm 1.23^{\mathrm{b}}$ \\
\hline & Kidney & $8.95 \pm 0.7$ & $22.38 \pm 1.55^{\mathrm{a}}$ & $18.43 \pm 3.02^{\mathrm{b}}$ & $12.43 \pm 3.05^{\mathrm{b}}$ & $17.9 \pm 1.45^{\mathrm{b}}$ \\
\hline \multirow{2}{*}{$\begin{array}{ll}\text { GSH } & (\mathrm{mg} / \mathrm{mg} \\
\text { protein }) & \end{array}$} & Liver & $2.24 \pm 0.1$ & $1.17 \pm 0.07^{\mathrm{a}}$ & $1.79 \pm 0.13^{\mathrm{b}}$ & $2.19 \pm 0.13^{\mathrm{b}}$ & $2.03 \pm 0.15^{\mathrm{b}}$ \\
\hline & Kidney & $2.52 \pm 0.08$ & $1.64 \pm 0.11^{\mathrm{a}}$ & $2.13 \pm 0.1^{\mathrm{b}}$ & $2.23 \pm 0.04^{\mathrm{b}}$ & $1.88 \pm 0.13^{\mathrm{b}}$ \\
\hline \multirow[t]{2}{*}{ CAT (U/g protein) } & Liver & $1.92 \pm 0.17$ & $0.83 \pm 0.02^{\mathrm{a}}$ & $1.31 \pm 0.04^{\mathrm{b}}$ & $1.67 \pm 0.02^{\mathrm{b}}$ & $1.55 \pm 0.12^{\mathrm{b}}$ \\
\hline & Kidney & $3.54 \pm 0.3504$ & $1.12 \pm 0.11^{\mathrm{a}}$ & $2.05 \pm 0.20^{\mathrm{b}}$ & $2.70 \pm 0.24^{\mathrm{b}}$ & $1.56 \pm 0.14^{\mathrm{b}}$ \\
\hline
\end{tabular}

Values are means \pm se $(n=10$ per group). a: Significant compared with a control group. b: significant compared with the EAC group.

\subsection{Histopathological examination of liver tissues.}

Sections in the liver of a control group revealed preserved lobular architecture. The portal tracts showed no inflammatory cellular infiltrate nor interface hepatitis. (Figure 1A). The portal tracts in the EAC group's liver showed moderate inflammatory cellular infiltration with mild interface hepatitis within sections. Moderate lobular inflammation and modest hydropic degeneration were seen in the hepatocytes. Moderate dysplastic changes are seen in the form of hyperchromatic nuclei and mild pleomorphism (Figure 1B). Sections examined from the liver biopsy of mice received $0.034 \mathrm{mg} / \mathrm{kg}$ NNSV revealed preserved lobular architecture. The portal tracts showed mild inflammatory cellular infiltrate with mild interface hepatitis. The hepatocytes showed moderate lobular inflammation and mild hydropic degeneration (Figure 1C). Sections in the liver of EAC rats treated with $0.034 \mathrm{mg} / \mathrm{kg}$ NNSV revealed they preserved lobular architecture. The portal tracts showed mild inflammatory cellular infiltrate with mild interface hepatitis. The hepatocytes showed marked lobular inflammation, mild hydropic degeneration, and mild dysplastic changes (Figure 1D). Sections in the liver of EAC rats treated with $0.017 \mathrm{mg} / \mathrm{kg}$ NNSV revealed they preserved lobular architecture. The portal tracts showed mild inflammatory cellular infiltrate with mild interface hepatitis. The hepatocytes showed moderate lobular inflammation and mild hydropic degeneration (Figure 1E). Sections in the liver of 5-FU treated revealed preserved lobular architecture. The portal tracts showed mild inflammatory cellular infiltrate with mild interface hepatitis. The hepatocytes showed no lobular inflammation (Figure 1F).

\subsection{Histopathological examination of kidney tissues.}

Sections in the kidney of a control group revealed normal glomeruli and average tubules. The interstitium showed no abnormality (Figure 2A). Sections examined from the EAC group's renal tissue markedly reduced glomerular size with capillary congestion, severe interstitial edema, and focal hemorrhage with marked tubular epithelial degeneration (Figure 2B). 

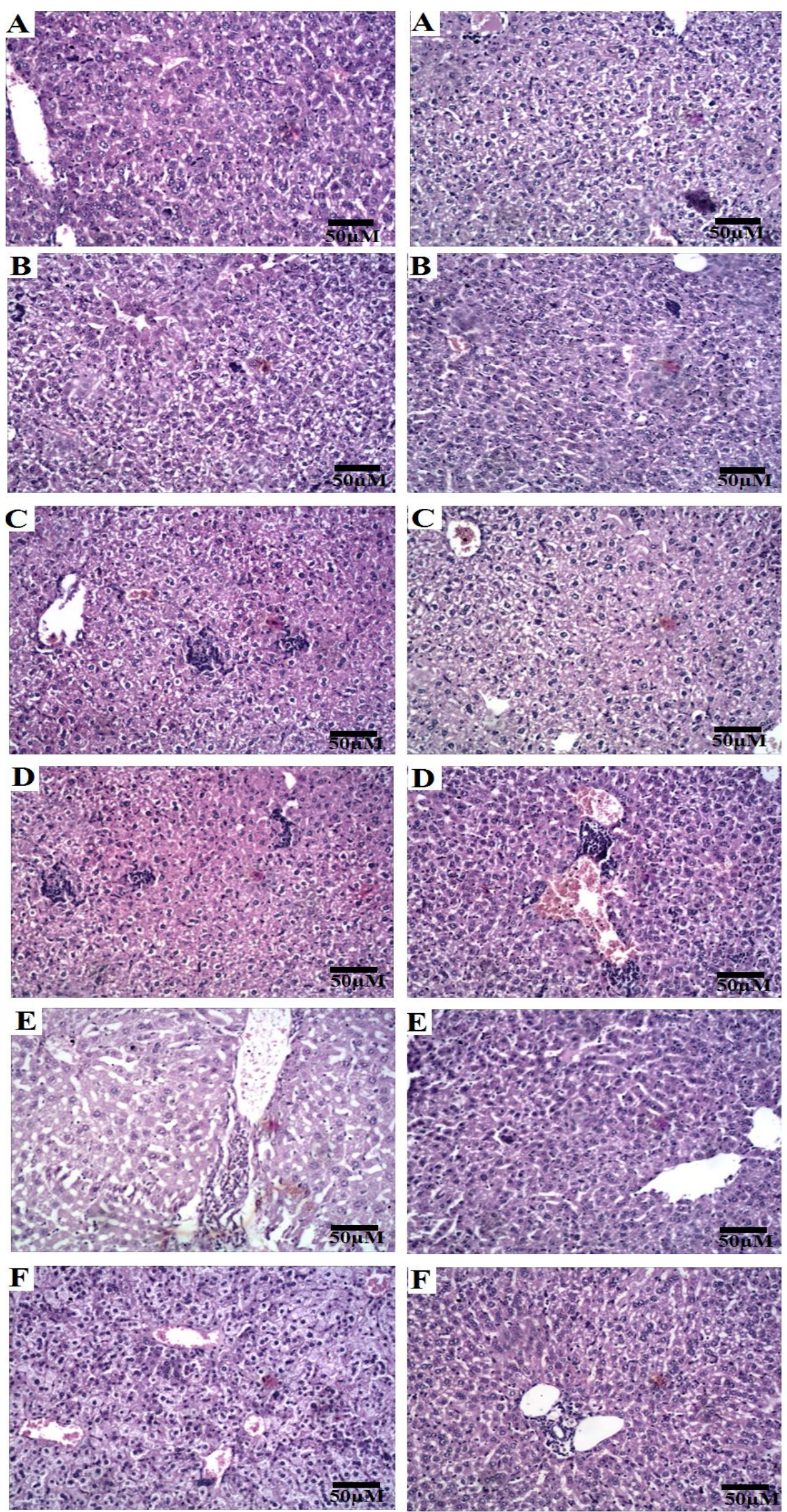

Figure 1. Photomicrograph of Hematoxylin and eosin-stained liver slices from A: control: B: EAC, C: NNSV $(0.034 \mathrm{mg} / \mathrm{kg}), \mathbf{D}:$ EAC+ NNSV $(0.034 \mathrm{mg} / \mathrm{kg}), \mathbf{E}:$ EAC+ NNSV $(0.017 \mathrm{mg} / \mathrm{kg})$, and F: $5-\mathrm{FU}(\mathrm{H} \& \mathrm{E} \times 400)$. 

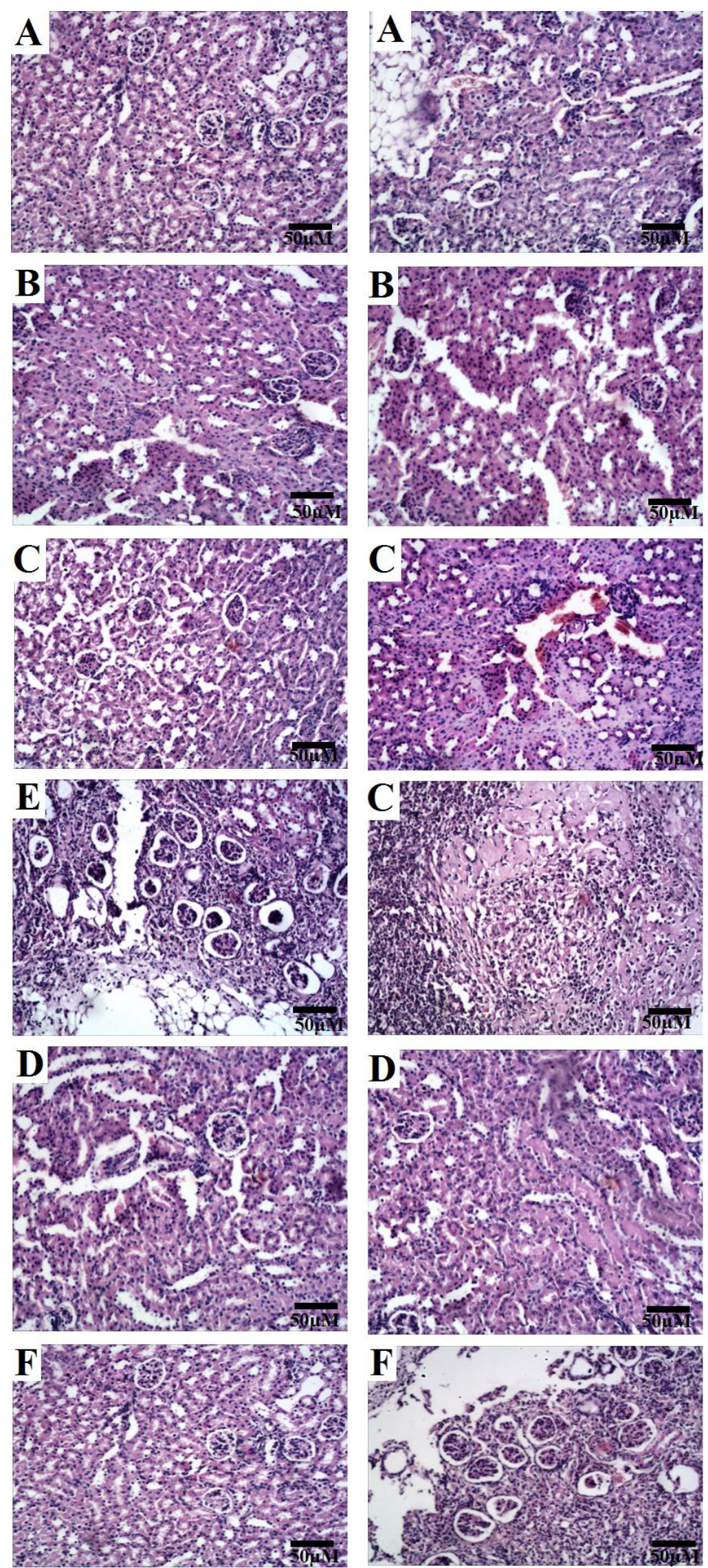

Figure 2. Photomicrograph of Hematoxylin and eosin-stained kidney slices from A: control: B: EAC, C: NNSV $(0.034 \mathrm{mg} / \mathrm{kg}), \mathbf{D}:$ EAC+ NNSV $(0.034 \mathrm{mg} / \mathrm{kg}), \mathbf{E}: \mathrm{EAC}+\mathrm{NNSV}(0.017 \mathrm{mg} / \mathrm{kg})$, and F: 5-FU (H\&E $\times 400)$.

Sections examined from the mice's kidney received $0.034 \mathrm{mg} / \mathrm{kg}$ NNSV revealed mild mesangial proliferation and average tubules showing intraluminal RBCs. The interstitium 
showed mild fibrosis (Figure 2C). Sections in the kidney of EAC rat treated with $0.034 \mathrm{mg} / \mathrm{kg}$ average tubules showing intraluminal RBCs. The interstitium showed mild inflammation and xanthogranulomatous reaction. (Figure 2D). Sections in the kidney of EAC rat treated with $0.017 \mathrm{mg} / \mathrm{kg}$ NNSV were revealed within normal glomeruli and average tubules. The interstitium showed no abnormality (Figure 2E). Sections in the kidney of 5-FU treated revealed within normal glomeruli and average tubules. The interstitium showed no abnormality (Figure 2F).

\section{Conclusions}

The current study showed that NNSV suppresses tumor growth, decreases lipid peroxidation, improves antioxi-dant status, and ameliorates liver and kidney functions of Swiss albino mice. The outcomes of this study show that NNSV is a powerful natural substance with intriguing anticancer properties. The $0.034 \mathrm{mg} / \mathrm{kg}$ dose of NNSV appears to be more effective against EAC cells than the $0.017 \mathrm{mg} / \mathrm{kg}$ dose of NNSV.

\section{Funding}

No funding sources.

\section{Acknowledgments}

The authors extend their appreciation to the Deanship of Scientific Research at Cairo University, Egypt, for supporting the current work.

\section{Conflicts of Interest}

The authors declare no conflict of interest.

\section{References}

1. Solomon, A.D. Market Analysis of Advance Cancer Research. ArchivesinCancerResearch 2019, 8, e 24-e 25.

2. Cancer Facts \& Figures 2019. American Cancer Society 2019, https://www.cancer.org/research/cancer-factsstatistics/all-cancer-facts-figures/cancer-facts-figures-2019.html.

3. Salem, M.L.; Shoukry, N.M.; Teleb, W.K.; Abdel-Daim, M.M.; Abdel-Rahman, M.A. In vitro and in vivo antitumor effects of the Egyptian scorpion Androctonus amoreuxi venom in an Ehrlich ascites tumor model. Springerplus 2016, 5, 570.

4. Chong, H.P.; Tan, K.Y.; Tan, C.H. Cytotoxicity of Snake Venoms and Cytotoxins From Two Southeast Asian Cobras (Naja sumatrana, Naja kaouthia): Exploration of Anticancer Potential, Selectivity, and Cell Death Mechanism. Front. Mol. Biosci 2020, 2020, 583587.

5. Albulescu, L.O.; Xie, C.; Ainsworth, S.; Alsolaiss, J.; Crittende, E.; Dawso, C.A.; Softley, R.; Bartlett, K. E.; Harrison, R.A.; Kool, J.; Casewell, N.R.A therapeutic combination of two small molecule toxin inhibitors provides broad preclinical efficacy against viper snakebite. Nat Commun 2020, 11, 6094.

6. Moga, M.A.; Dimienescu, O.G.; Arvătescu, C.A.; Ifteni, P.; Pleş, L. Anticancer Activity of Toxins from Bee and Snake Venom-An Overview on Ovarian Cancer. Molecules 2018, 23, 692.

7. Li, L.; Huang, J.; Lin, Y. Snake Venoms in Cancer Therapy: Past, Present and Future. Toxins (Basel) 2018, $10,346$.

8. Wallach, V.; Wuster, W.; Broadley, D.G. In praise of subgenera: Taxonomic status of cobras of the genus Naja Laurenti (Serpentes: Elapidae). Zootaxa 2009, 2236, 26-36.

9. Wüster, W.; Broadley, D. A new species of spitting cobra (Naja) from north-eastern Africa (Serpentes: Elapidae). Journal of Zoology 2003, 259, 345-359.

10. Aliu; Nwude. Veterinary Pharmacology and Toxicology Experiments. 1982. 
11. Dagli; Guerra; Saldiva; P.H.N. An experimental study on the lymphatic dissemination of the solid Ehrlich tumor in mice. 1992, No. 29.

12. Kavitha, C. N.; Raja, K. D.; Rao, S. K. Antitumor activity of Albizia lebbeck L. against Ehrlich ascites carcinoma in vivo and HeLa and A549 cell lines in vitro. J Can Res Ther 2021, 17, 491-498.

13. Mohamed, A.S.; Hosney, M.; Bassiony, S.; Hassanein, S.S.; Soliman, A.M.; Fahmy, S.R.; Gaafar, K. Sodium pentobarbital dosages for exsanguination afect biochemical, molecular and histological measurements in rats. Scientific Reports 2020, 10, 378, https://doi.org/10.1038/s41598-019-57252-7.

14. Sadek, S.A.; Hassanein, S.S.; Mohamed, A.S.; Soliman, A.M.; Fahmy, S.R. Echinochrome pigment extracted from sea urchin suppress the bacterial activity, inflammation, nociception, and oxidative stress resulted in the inhibition of renal injury in septic rats. Journal of food biochemistry 2021, 2021, e13729, https://doi.org/10.1111/jfbc.13729.

15. Farag, N.A.; Mohamed, A.S.; El Sayed, H.F.; Salah EL-Din, E.Y.; Tawfik, A.A. Echinochrome Pigment Improves Male Rats' Fertility. The Natural Products Journal 2020, 10, 1.

16. Mohamed, A.S.; Bin Dajem, S.; Al-Kahtani, M.; Ali, S.B.; Ibrahim, E.; Morsy, K.; Fahmy, S.R. Silver/chitosan nanocomposites induce physiological and histological changes in freshwater bivalve. Journal of Trace Elements in Medicine and Biology 2021, 65, 126719.

17. El-Sisi, A.A.; Fahmy, S.R.; El-Desouky, M.A.; El-Tawil, O.; Mohamed, A.S.; El-Sherif, A.A. Protective roles of novel thiosemicarbazone derivatives on hepatotoxicity and nephrotoxicity induced by cadmium chloride in rats. Acta Poloniae Pharmaceutica - Drug Research 2021, 78, 193-203.

18. Akhtar, B.; Muhammad, F.; Sharif, A.; Anwar, M.I. Mechanistic insights of snake venom disintegrins in cancer treatment. European Journal of Pharmacology 2021, 899, 174022.

19. Gupta, A.; Sedhom, R.; Beg, M.S. Ascites, or Fluid in the Belly, in Patients With Cancer. JAMA Oncology 2020, 6.

20. Oršolić, N.; Kunštić, M.; Kukolj, M.; Odeh, D.; Ančić, D. Natural Phenolic Acid, Product of the Honey Bee, for the Control of Oxidative Stress, Peritoneal Angiogenesis, and Tumor Growth in Mice. Molecules 2020, 52, 5583.

21. Emara, A.A.; Dawood, M.F.; Abdallah, W.A.; Hazaa, A.Z.; Ahmed, A.A.; Elbayoumy, A.S.; El-nossairy, A.M.; Yaqoub, N.S.; Khalifa, S.H.; Abdelaziz, E.O.; Khairy, A.B.; Gobba, N.A.; Abdalla, E.A.; Hegazy, I.; Hussein, M. A. Mechanism of Anti-Angiogenic and Renal Protective Activity of Balanites aegyptiaca Seeds Extract in Ehrlich Ascites Carcinoma-Bearing Mice. Pakistan Journal of Nutrition 2021, 20, 46-54.

22. Madeddu, C.; Gramignano, G.; Astara, G.; Demontis, R.; Sanna, E.; Atzeni, V.; Macciò, A. Pathogenesis and Treatment Options of Cancer Related Anemia: Perspective for a Targeted Mechanism-Based Approach. Front Physiol 2018, 9, 1294.

23. Mohamed, A. S. Echinochrome Exhibits Antitumor Activity against Ehrlich Ascites Carcinoma in Swiss Albino Mice. Nutrition and Cancer 2021, 73, 124-132, https://doi.org/10.1080/01635581.2020.1737152.

24. Nakamura, K.; Smyth, M.J. Aberrant erythropoiesis fuels tumor growth. Cell Res 2018, 28, 611-612.

25. Haldar, P.K.; Kar, B.; Bala, A.; Bhattacharya, S.; Mazumder, U.K. Antitumor activity of Sansevieria roxburghiana rhizome against Ehrlich ascites carcinoma in mice. Pharmaceut Bio 2010, 48, 1337-1343.

26. Mohamed, A.S.; Mahmoud, S.A.; Soliman, A.M.; Fahmy, S.R. Antitumor activity of saponin isolated from the sea cucumber, holothuria arenicola against ehrlich ascites carcinoma cells in swiss albino mice. Natural product research 2021, 35, 1928-1932, https://doi.org/10.1080/14786419.2019.1644633.

27. Rosner, M.H.; Jhaver, K.D.; McMahon, B.A.; Perazella, M.A. Onconephrology: The intersections between the kidney and cancer. CA: A Cancer Journal for Clinicians 2020, 71, 47-77.

28. Abu-Sinna, G.; Esmat, A.M.; Al-Zahaby, S.; Soliman, N.A.; Ibrahim, T.M. Fractionation and characterization of Cerastes cerastes cerastes snake venom and the antitumor action of its lethal and nonlethal fractions. Toxicon 2003, 42, 207-215.

29. Mohamed, A.S.; Bin Dajem, S.; Al-Kahtani, M.; Ali, S.B.; Ibrahim, E.; Morsy, K.; Fahmy, S.R. Silver/chitosan nanocomposites induce physiological and histological changes in freshwater bivalve. Journal of Trace Elements in Medicine and Biology 2021, 65, 126719, https://doi.org/10.1016/j.jtemb.2021.126719.

30. Abdel-Rahman, M. A.; Abdel-Nabi, I. M.; El-Naggar, M. S.; Abbas, O. A.; Strong, P. N. Conus vexillum venom induces oxidative stress in Ehrlich's ascites carcinoma cells: an insight into the mechanism of induction. J. VenoM. Animal Tox.Tropi. Dise. 2013, 2013, 10.

31. Zeng, D.; Wang, Y.; Chen, Y.; Li, D.; Li, G.; Xiao, H.; Hou, J.; Wang, Z.; Hu, L.; Wang, L.; Li, J. Angelica Polysaccharide Antagonizes 5-FU-Induced Oxidative Stress Injury to Reduce Apoptosis in the Liver Through Nrf2 Pathway. Front. Oncol 2021, 2021, 720620. 